Arch Virol (2000) 145: 2335-2349

Archives of
Virology
OSpringer-vertag 2000
Prined in Austria

\title{
Antibody responses to respiratory coronavirus infections of cattle during shipping fever pathogenesis
}

\author{
X. Q. Lin ${ }^{1}$, K. L. O'Reilly ${ }^{1}$, J. Storz ${ }^{1}$, C. W. Purdy ${ }^{2}$, and R. W. Loan ${ }^{3}$ \\ ${ }^{1}$ Department of Veterinary Microbiology and Parasitology, School of Veterinary Medicine, \\ Louisiana State University, Baton Rouge, Louisiana U.S.A. \\ ${ }^{2}$ Conservation and Production Research Laboratory, USDA, ARS, Bushland, Texas, U.S.A. \\ ${ }^{3}$ Department of Veterinary Pathobiology, Texas A\&M University, College Station, \\ Texas, U.S.A.
}

Accepted May 11, 2000

Summary. Antibody responses against respiratory bovine coronavirus (RBCV) infections were monitored in cattle from the onset of a naturally occurring severe shipping fever (SF) epizootic to complete recovery of affected cattle or fatal outcomes. The infection with RBCV was detected in nasal secretions of 86 cattle, and 81 of them developed acute respiratory tract disease, including fatal pneumonia. Cattle nasally shedding RBCV at the beginning of the epizootic experienced characteristic primary immune responses with specific antibodies for hemagglutininesterase (HE) and spike (S) glycoproteins. Virus shedding in nasal secretions of the majority of the cattle ceased between days 7 and 14 with the appearance of HE- and S-specific antibodies. Nasal samples and lung tissues from 9 of the 10 fatal cases had high titers of RBCV, but these cattle had only IgM responses to $\mathrm{RBCV}$ infections. Cattle remaining negative in RBCV isolation tests entered this epizootic with antibodies against HE and S. Protection against respiratory tract disease was apparently associated with high level of opsonic and virus-neutralizing $\operatorname{IgG} 2$. The HE and S glycoproteins were recognized earliest by the bovine immune system while the $\mathrm{N}$ protein induced antibody responses during the later stage of initial infection and the early stage of reinfection. The membrane (M) glycoprotein was the least immunogenic of the major viral structural proteins.

\section{Introduction}

Coronaviruses, a genus in the family Coronaviridae, are enveloped, positivestrand RNA viruses that emerge as increasingly important causes of human and animal diseases. These diseases include respiratory infections, gastroenteritis, 
hepatic and neurological disorders, immune-mediated disease such as feline infectious peritonitis, and persistent infections $[15,28]$. Bovine coronavirus (BCV) is the second most common cause of virus-induced severe enteritis or occasional pneumoenteritis in calves, and is referred to here as enteropathogenic BCV (EBCV) [5, 21]. Winter dysentery in adult dairy cattle was also attributed to EBCV $[5,25]$.

Recently, high rates of coronavirus infections were detected in respiratory tract samples of cattle with acute respiratory distress including shipping fever (SF) [30-33, 37]. Shipping fever is an acute respiratory tract disease particularly prevalent among 6- to 8-month-old cattle after transport and entry into feed yards in North America [11, 41]. The role of respiratory bovine coronavirus (RBCV) in $\mathrm{SF}$ was previously not recognized. A refined virus isolation scheme was applied in recent etiological investigations. It included the $\mathrm{G}$ clone of human rectal tumor18 (HRT-18) cells, Georgia bovine kidney (GBK) and bovine turbinate (BT) cells with specific permissiveness for currently known respiratory viruses of cattle including RBCV [30-33, 37]. This approach led to the first successful isolation of wild-type RBCV at high rates from nasal swab samples of cattle arriving at feed yards with respiratory distress, and provided the initial evidence of a potential etiological role of RBCV in SF.

The genome of EBCV consists of a single, positive-stranded RNA molecule of about 31 kilobases $(\mathrm{kb})[5,15,28]$. The $3^{\prime}$ end of the genomic RNA consists of approximately $9.5 \mathrm{~kb}$ and contains the genes for 5 structural proteins: (i) a longer peplomeric 200-kilodalton $(\mathrm{kDa})$ spike glycoprotein $(\mathrm{S})$ with a proteolytic cleavage site where proteases split S into 110-kDa S1 and 100-kDa S2 subunits, (ii) a short peplomeric 140-kDa hemagglutinin-esterase glycoprotein (HE) which is a disulfide-linked dimer of 2 identical $65-\mathrm{kDa}$ subunits, (iii) a 26-kDa integral membrane glycoprotein (M), (iv) a 9.5-kDa envelope protein (E), and (v) an internal phosphorylated $50-\mathrm{kDa}$ nucleocapsid protein $(\mathrm{N})[1,7,12]$. Phenotypic and genotypic properties of RBCV differentiated them from EBCV [4, 30-33, 37]. The distinguishing features are: (i) The RBCV were isolated in the $1^{\text {st }} \mathrm{G}$ clone cell passage without trypsin enhancement. Trypsin activation was required for the isolation of EBCV [36]. (ii) The RBCV have unusually high cell-fusing activities for the $\mathrm{G}$ clone cells. (iii) The RBCV have a restricted hemagglutination pattern, and agglutinate only mouse and rat, but not chicken red blood cells (RBC). The EBCV prototypes agglutinate both rodent and chicken RBC [38]. (iv) The RBCV have the highest acetylesterase (AE) activities at $37^{\circ} \mathrm{C}$ while the $\mathrm{AE}$ functions of EBCV are more active at $39^{\circ} \mathrm{C}$ [17]. (v) Comparative nucleotide (n.t.) and amino acid (a.a.) sequence analysis of the $3^{\prime}$ genomic portion $(9.5 \mathrm{~kb})$ of wild-type $\mathrm{RBCV}$ and $\mathrm{EBCV}$ strains revealed that RBCV-specific n.t. and a.a. changes were disproportionally concentrated within the HE gene, the $S$ gene and the genomic region between the $S$ and $E$ genes [4].

Immunoglobulin (Ig) $\mathrm{G}$ predominates over other classes in serum of cattle and accounts for around $90 \%$ of the total serum $\operatorname{Ig}[8,20,39]$. The 2 major subclasses of IgG in cattle are IgG1 and IgG2 [2]. Although IgG1 and IgG2 occur in relatively equal amounts in serum and secretions, IgG1 is the predominant 
isotype in colostrum and milk. Bovine IgG1 and $\mathrm{IgG} 2$ fix bovine complement, but IgG2 does not bind heterologous complement $[18,19]$. The antibody responses to EBCV structural proteins were studied in 5 experimentally exposed, colostrumdeprived, 20- to 30-hour-old calves that were inoculated orally and intranasally at birth and challenge exposed 3 weeks after inoculation [10]. About 2 to 3 days postinoculation, these calves developed enteric disease signs, and virus shedding was detected in their feces and nasal swab samples for 4 to 9 days and 6 to 9 days, respectively. These calves first developed serum $\operatorname{IgM}$ to $\mathrm{N}$ and $\mathrm{HE}$ at postinoculation week (PIW) 1, and then they responded with IgG1 directed to N and $\mathrm{S}$, and with moderate and slower $\mathrm{IgG} 2$ response to $\mathrm{N}$ and $\mathrm{S}$ antigens at PIW 2 and 3. After challenge of the immunity of these calves by EBCV inoculation, virus shedding was not detected, and calves did not become ill. An increase in IgM to $\mathrm{N}$, in $\mathrm{IgG} 1$ antibody reactions to $\mathrm{S}, \mathrm{HE}, \mathrm{M}$ and $\mathrm{N}$, and in $\mathrm{IgG} 2$ responses to $\mathrm{S}$ and $\mathrm{HE}$ was detected. The $\mathrm{S}$ and $\mathrm{HE}$ antigens elicited virus infectivity-neutralizing antibodies.

Previous investigations on the kinetics of antibody responses of cattle to respiratory viruses other than RBCV demonstrated a crucial role of Ig isotypes in disease development and protection $[11,13,14,16,23,24,41]$. Consequently, we monitored antibody responses to RBCV infections during a severe SF epizootic which was prospectively designed, and included sequential examinations and samplings. These cattle were studied clinically, virologically and immunologically from the initial phases of infection to recovery or fatal outcomes. The investigation facilitated the first comprehensive assessment of currently prevailing respiratory virus infections of market-stressed cattle during a naturally occurring epizootic. A surprisingly high rate of RBCV infections in the virtual absence of other respiratory bovine viruses was detected in the early stage of this epizootic [30-33]. The specific objectives of this report were to assess the kinetics of total antibody responses of immunologically mature cattle to RBCV infections during a naturally occurring SF epizootic, to define the immunoisotype responses and the antigenic reactivities of the $\mathrm{S}, \mathrm{HE}, \mathrm{M}, \mathrm{N}$ structural proteins of $\mathrm{RBCV}$, and to relate these findings with isolation of RBCV from nasal swab and lung samples and development of respiratory tract disease.

\section{Materials and methods}

\section{Experimental design}

One hundred and five 6- to 8-month-old cattle were included in this naturally evolving and prospectively monitore epizootic which occurred in 1997. The mixed-breed cattle were assembled on day 0 at an order-buyer barn (OBB), identified by ear tags and clinically examined. Nasal swab and blood samples were collected, followed by vaccination with commercially available modified-live vaccines against BHV-1 and PI-3 (Prevail, Rhone Merieux Inc.), and a 7-way clostridial vaccine (Electroid 7, Mallinckrodt Veterinary Inc.). After a stay at the OBB, the cattle were transported 1932 kilometers to the feed yard jointly operated by the Agricultural Research Service and the Texas Agricultural Experimental Station in Bushland, Texas. Nasal swab samples were taken on days 7, 14, and 21, and blood for serum harvest was collected on days 7, 14, 21, 28 and 35 . 
Table 1. Respiratory coronavirus isolations and clinical signs of cattle in response groups of the 1997 shipping fever epizootic

\begin{tabular}{|c|c|c|c|c|c|c|c|c|}
\hline \multirow{2}{*}{$\begin{array}{l}\text { Response } \\
\text { group }\end{array}$} & \multirow{2}{*}{$\begin{array}{l}\text { No. of } \\
\text { cattle }\end{array}$} & \multicolumn{4}{|c|}{ No. of RBCV isolation-positive cattle } & \multicolumn{2}{|c|}{ Clinical signs } & \multirow{2}{*}{$\begin{array}{l}\text { No. of } \\
\text { Ab-tested cattle }\end{array}$} \\
\hline & & Day 0 & Day 7 & Day 14 & Day 21 & RTD & Death & \\
\hline $1 \mathrm{a}$ & 12 & 12 & 0 & 1 & 0 & Yes & No & 7 \\
\hline $1 \mathrm{~b}$ & 44 & 44 & 44 & 2 & 3 & Yes & No & 7 \\
\hline $1 \mathrm{c}$ & 6 & 0 & 16 & 1 & 1 & Yes & No & 7 \\
\hline 2 & 5 & 2 & 3 & 1 & 0 & No & No & 5 \\
\hline 3 & $10^{\mathrm{a}}$ & 6 & 9 & & & Yes & Yes & 9 \\
\hline 4 & 11 & 0 & 0 & 0 & 0 & Yes & No & 7 \\
\hline 5 & 7 & 0 & 0 & 0 & 0 & No & No & 7 \\
\hline Total & 105 & 64 & 72 & 5 & 4 & & & 49 \\
\hline
\end{tabular}

$\mathrm{RBCV}$, respiratory bovine coronavirus; RTD, clinical signs of respiratory tract disease; ${ }^{\mathrm{a}}$ Cattle died on days 7 to 11

Clinical signs of respiratory tract diseases and results of RBCV isolation assigned these cattle into 5 response groups based on results reported elsewhere (Table 1) [31-33]. Response group 1 included 72 cattle that exhibited clinical signs of respiratory tract disease, and were shedding RBCV on day 0 , day 7 or both. Seven animals were randomly chosen from each shedding pattern for testing in this study. Response group 2 contained 5 test cattle that secreted RBCV in nasal discharges without adverse respiratory signs. The 10 cattle of response group 3 developed severe pneumonia, and died on days 7 to 11 , and 9 that nasally shed RBCV were selected. Eighteen cattle remained RBCV isolation-negative. Eleven of them were included in response group 4 because they had fever and other respiratory signs, while the remaining 7 calves (response group 5) remained clinically healthy during the 5-week investigation. Samples of 7 representative cattle from response groups 4 and 5 were serologically analyzed. Test results of 49 cattle on sequential serum samples were included in this report.

\section{Cell line and virus isolate}

The $\mathrm{G}$ clone of HRT- 18 cells was used at the $24^{\text {th }}$ passage level for RBCV propagation. A wild-type strain RBCV-97TXSF-Lu15-2 was used at its $2^{\text {nd }}$ passage for antigen preparation after initial isolation from the lung tissue of a calf that died on day 8 [31, 32].

\section{Virus purification}

Virus purification was performed according to Zhang et al. [42]. Infected G clone cultures with $90 \%$ cytopathic expression were subjected to 3 cycles of freezing and thawing, sonication for $4 \times 15 \mathrm{sec}$ at power setting 4 of a Branson Sonifier cell disruptor 200 (Branson Ultrasonics Co), and centrifugation at $1,500 \times \mathbf{g}$ for $30 \mathrm{~min}$. Supernatant fluids were collected, precipitated overnight at $4{ }^{\circ} \mathrm{C}$ with $10 \%(\mathrm{w} / \mathrm{v})$ polyethylene glycol 8,000 and $0.5 \mathrm{M}$ $\mathrm{NaCl}$ in TNE buffer (100 mM Tris, $10 \mathrm{mM} \mathrm{NaCl}, 1 \mathrm{mM}$ EDTA, pH 7.4), and harvested by centrifugation at $1,500 \times \mathbf{g}$. Suspensions of precipitates were loaded onto a $20 \%$ sucrose cushion prepared in TNE buffer, centrifuged at $90,000 \times \mathbf{g}$ for $2 \mathrm{~h}$. The sediments were collected and purified by centrifugation at $200,000 \times \mathbf{g}$ for $16 \mathrm{~h}$ through a $20-60 \%$ sucrose gradient prepared in TNE buffer. Isopycnic bands were collected, and the sucrose was removed through TNE 
buffer dilution and centrifugation at $200,000 \times \mathbf{g}$ for $1.5 \mathrm{~h}$. The purified virus preparations were resuspended in TNE buffer and stored at $-70^{\circ} \mathrm{C}$.

Antibody detection using indirect enzyme-linked immunosorbent assay (ELISA)

The purified RBCV-97TXSF-Lu15-2 stock was diluted to $1 \mu \mathrm{g}$ protein $/ \mathrm{ml}$ in $0.1 \mathrm{M}$ carbonate buffer, $\mathrm{pH}$ 9.6, and used to coat Microtitration ELISA plates (Immulon-2, Fisher Scientific). The coated plates were held overnight at $4{ }^{\circ} \mathrm{C}$, and blocked for $2 \mathrm{~h}$ at room temperature with NET buffer ( $0.15 \mathrm{M} \mathrm{NaCl}, 1 \mathrm{mM}$ EDTA, $0.05 \mathrm{M}$ Tris, $\mathrm{pH} 7.4)$ containing $1 \%$ (w/v) bovine serum albumin (BSA) and $0.2 \%(\mathrm{v} / \mathrm{v}) \mathrm{NaN}_{3}$. Plates were washed 5 times with NET buffer containing $0.05 \%(\mathrm{v} / \mathrm{v})$ Tween-20 prior to addition of each reagent $(100 \mu \mathrm{l} /$ well $)$. All the reagents were added at $100 \mu \mathrm{l} /$ well. Serum samples diluted 1:50 in NET buffer containing $1 \%$ BSA were added in triplicate to appropriate wells. Serum $1745[34,35]$ was included as positive control in the test while RBCV-antibody free serum from a normal calf [34, 35] served as negative control. Plates were incubated for $30 \mathrm{~min}$ at room temperature and washed as described above. Horseradish peroxidase (HRPO)-conjugated, affinity-purified goat anti-bovine $\mathrm{IgG}(\mathrm{H}+\mathrm{L})$ (Jackson Immunoresearch Inc.) diluted at 1:20,000 was added for total Ig detection. A 1:400 dilution of HRPO-conjugated sheep anti-bovine IgM, a 1:30,000 dilution of HRPO-conjugated sheep anti-bovine IgG1, and a 1:4,000 dilution of HRPOconjugated sheep anti-bovine IgG2 (Bethyl Laboratories Inc.) were used for IgM, IgG1 and $\mathrm{IgG} 2$ isotype quantitation, respectively. Plates were incubated for another $30 \mathrm{~min}$ and washed as described above. The substrate solution containing $\mathrm{H}_{2} \mathrm{O}_{2}$ and the chromogen 3,3',5,5'-tetramethylbenzidine (Kirkegarrd \& Perry Laboratories Inc.) was added. Plates were incubated for $5 \mathrm{~min}$, and then reactions were stopped by addition of $100 \mu \mathrm{l}$ of $0.10 \mathrm{M} \mathrm{H}_{2} \mathrm{SO}_{4}$. The optical density (OD) was measured with an ELISA plate reader (Dynatech MR 5000, Dynatech Laboratories Inc.) at $450 \mathrm{~nm}$. The $\mathrm{OD}_{450}$ values of triplicate wells were averaged for each test serum.

\section{Statistical assessments}

The kinetics of total and isotype-specific antibody responses in each response group are presented as means \pm standard error of the mean (SEM) of $\mathrm{OD}_{450}$ values. The antibody responses were compared by an analysis of variance of repeated measures designed with a split-plot arrangement of treatments. Pairwise comparisons of treatment and day differences were conducted with Scheffe's test. Interaction effects were examined with pairwise t-tests of least square means for pre-planned comparisons of treatments at specific day levels. All tests were considered significant at a probability of $P<0.05$.

\section{Immunoblot assays}

Purified RBCV-97TXSF-Lu15-2 (1 mg protein/ml) at a volume of $250 \mu \mathrm{l}$ was mixed with an equal volume of $2 \times$ sample buffer [0.125 M Tris, $20 \%(\mathrm{v} / \mathrm{v})$ glycerol, $10 \%(\mathrm{v} / \mathrm{v}) 2$ 2Mercaptoethanol, $4.6 \%$ (w/v) SDS] and heated to $100^{\circ} \mathrm{C}$ for $5 \mathrm{~min}$. A $500-\mu \mathrm{l}$ volume of this virus preparation was separated by electrophoresis in a $12 \%(\mathrm{w} / \mathrm{v})$ polyacrylamide minigel (BioRad Laboratories) at 100 volts for $60-75 \mathrm{~min}$. Proteins in the polyacrylamide gel were then electrophoretically transferred to pure nitrocellulose protein transfer membranes (Schleicher \& Schuell) at 100 volts for 90 min using an electrophoretic transfer cell (MiniTrans-Blot, BioRad Laboratories). Blotted membranes were blocked overnight at $4{ }^{\circ} \mathrm{C}$ with $10 \%(\mathrm{w} / \mathrm{v})$ nonfat-dry milk in NET buffer. The blot was mounted in a 28 chamber miniblotter apparatus (Miniblotter 28, Immunetics). Twenty serum samples diluted 1:5 were tested on each blot in separate lanes for $1 \mathrm{~h}$ at room temperature. Again, serum 1745 and RBCVantibody free serum from a normal calf were included as positive and negative controls, 
respectively $[34,35]$. Bound antibodies were localized after $1 \mathrm{~h}$-incubation at room temperature with HRPO-conjugated, affinity-purified goat anti-bovine $\operatorname{IgG}(\mathrm{H}+\mathrm{L})$ (Jackson Immunoresearch Inc.) diluted 1:5,000. All dilutions were made with 10\% nonfat-dry milk in NET buffer. Antibody bound conjugate was detected using ECL Western Blot Detection System (Amersham Life Science Inc.). Finally, the blot was exposed to Hyperfilm (Amersham Life Science Inc.)

\section{Results}

\section{Isolation of $R B C V$ and respiratory tract disease in response groups}

The results of RBCV isolation and signs of respiratory tract disease were correlated in Table 1. Respiratory bovine coronaviruses were isolated from nasal swab samples of 72 cattle which had mucopurulent nasal discharges, depression and rectal temperatures of $40^{\circ} \mathrm{C}$ or above (response group 1). Fifty-six of them nasally shed RBCV on day 0 (subgroup 1a, 1b). Sixteen additional cattle became infected during transport (subgroup 1c) while 12 cattle discontinued virus shedding on day 7 (subgroup 1a). Four calves continued to shed RBCV on days 14 and 21. Response group 2 contained 5 cattle which did not show adverse respiratory signs, but secreted RBCV in nasal discharges on day 0 or day 7 , and 1 of them continued shedding through day 14 . Ten cattle (response group 3 ) developed severe pneumonia and died from respiratory failure on days 7 to 11 . Virus isolations on nasal swab samples proved that 6 of them shed RBCV on days 0 and 7 while 3 had become infected by day 7 . The pneumonic lung tissues of these 9 cattle contained RBCV infectivity reaching titers of $5 \times 10^{6}$ plaque forming units per gram. The remaining case was $\mathrm{RBCV}$ isolation-negative. However, RBCV-specific genomic portions were detected in the lungs by an RT-PCR assay [3]. Eighteen of the 95 remaining cattle did not yield RBCV from sequential nasal swab samples, eleven (response group 4) had mild respiratory signs, while the other 7 calves remained clinically healthy throughout the entire epizootic (response group 5).

\section{Total and isotype-specific antibody responses to RBCV infections}

Differences in the 5-week total and isotype antibody responses between subgroups $1 \mathrm{a}, 1 \mathrm{~b}$ and $1 \mathrm{c}$ were not statistically significant, and findings on these 21 cattle were combined for pertinent analyses. Overall kinetics of total and isotype antibody responses for response group 1 and 2 did not show significant changes (Fig. 1A, $1 \mathrm{~B}, 1 \mathrm{~F}$ and $1 \mathrm{G})$. Levels of total antibodies to RBCV for all surviving cattle with active RBCV infections of the respiratory tracts (response groups 1 and 2) were initially low with $\mathrm{OD}_{450}$ values of $0.29 \pm 0.03$ and $0.33 \pm 0.05$ for cattle with and without signs of respiratory distress (Fig. 1A and 1B). The increases in these levels were statistically significant between days 7 and 14, and then remained at high

Fig. 1. Levels of total $(\mathbf{A}, \mathbf{B}, \mathbf{C}, \mathbf{D}, \mathbf{E})$ and isotype antibodies $(\mathbf{F}, \mathbf{G}, \mathbf{H}, \mathbf{I}, \mathbf{J})$ to respiratory bovine coronavirus in serum from cattle of response groups $1(\mathbf{A}, \mathbf{F}), 2(\mathbf{B}, \mathbf{G}), 3(\mathbf{C}, \mathbf{H}), 4$ (D, I) and 5 (E, J) during the 1997 shipping fever epizootic. • Total Ig and IgM; ○ IgG1; $\boldsymbol{\nabla}$ IgG2. Data are means \pm standard errors of the means $(n=21,5,9,7$ and 7 for $A+F, B+G$, $\mathrm{C}+\mathrm{H}, \mathrm{D}+\mathrm{I}$, and $\mathrm{E}+\mathrm{J}$, respectively) 


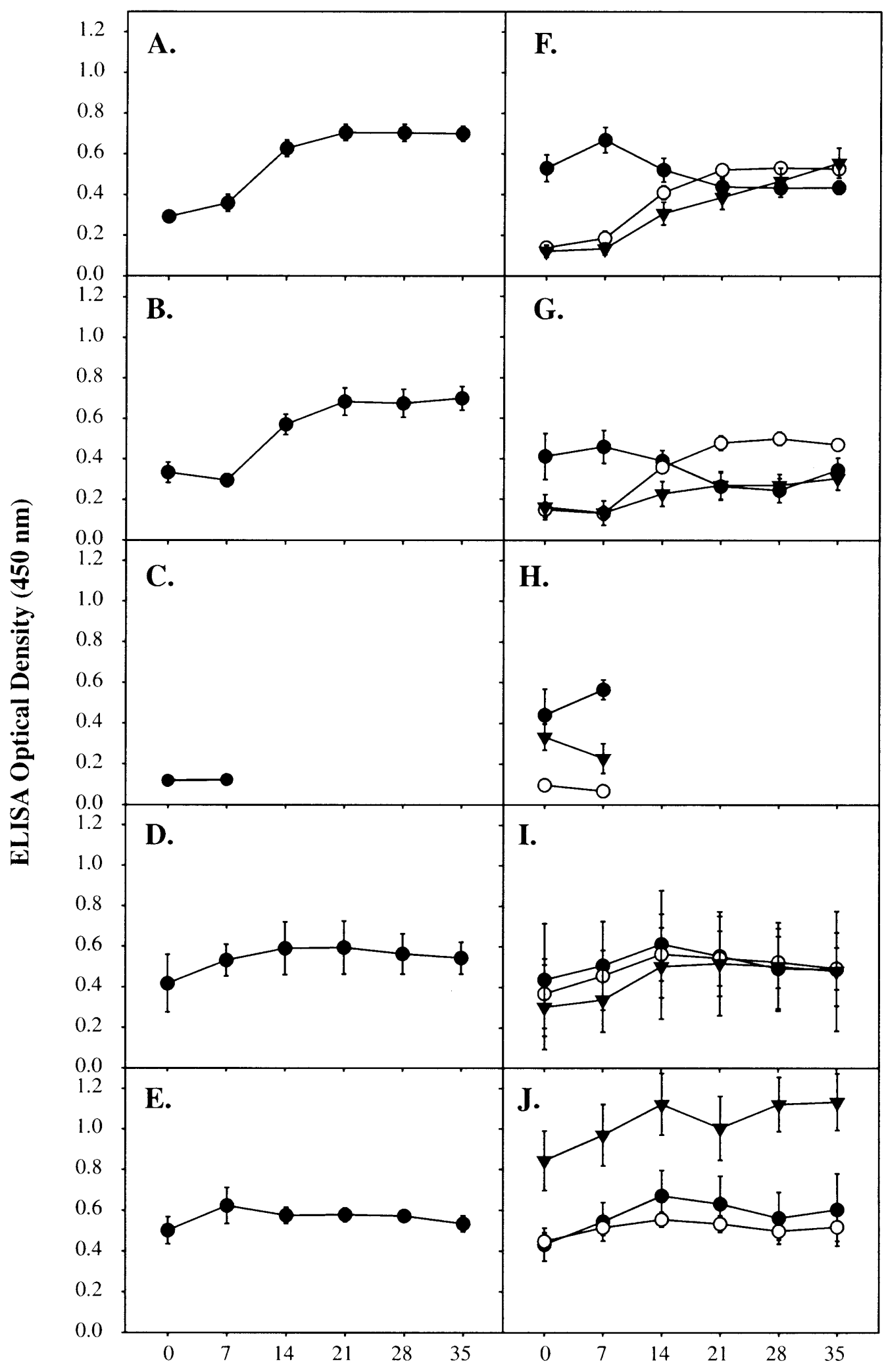

Day Post-arrival at Order-buyer Barn 
$\mathrm{OD}_{450}$ values reaching $0.71 \pm 0.04$ and $0.68 \pm 0.07$. In comparison with those for response group 2, $\mathrm{OD}_{450}$ values of $\mathrm{IgM}$ isotype for response group 1 were higher on days 0 and 7; and these differences were statistically significant (Fig. 1F and $1 \mathrm{G})$. As the IgM levels began to decline after day 7, levels of IgG1 and IgG2 isotype antibodies began to rise. Interestingly, calves of response group 1 had a more dramatic increase in $\mathrm{IgG} 2$ antibody level than cattle of response group 2 during days 14 and 35 .

Nine RBCV isolation-positive cattle with fatal pneumonia in response group 3 had low immune responses on day 0 as $\mathrm{OD}_{450}$ values for total $\operatorname{Ig}, \operatorname{IgM}, \operatorname{IgG} 1$, and $\mathrm{IgG} 2$ antibodies were $0.12 \pm 0.02,0.44 \pm 0.13,0.10 \pm 0.01$, and $0.33 \pm 0.06$, respectively (Fig. 1C and $1 \mathrm{H}$ ). Increases in antibody levels were not detected during the 7- or 8-day course of respiratory tract disease pathogenesis except for a minimal initial IgM response.

Cattle in response group 4 started at a relatively high and stable level of total antibody with $\mathrm{OD}_{450}$ values of $0.42 \pm 0.06$, and $0.53 \pm 0.03$ on days 0 and 7 which showed statistically significant increases from response groups 1 and 2 (Fig. 1A, $1 \mathrm{~B}$ and 1D). The total antibody levels increased to $0.59 \pm 0.05$ on day 14 and were maintained throughout the testing period. Kinetics of isotype antibody responses reflected that of the total antibody response (Fig. 1I). Compared with cattle of response groups 1 and 2, response group 4 cattle also had a higher IgG1 level during the first 2 weeks, and the increases were statistically significant (Fig. 1F, $1 \mathrm{G}$ and $1 \mathrm{I})$. The IgG2 level of response group 4 was significantly higher than that of response group 1 during the first week, and was also substantially higher than that of response group 2 in weeks 2 through 5.

Significant differences were not observed in the total, IgM and IgG1 antibody responses between response groups 4 and 5 during the entire period of this epizootic (Fig. 1D, 1E, 1I and 1J). However, during the time of observation, cattle in response group 5 had the highest level of $\mathrm{IgG} 2$ isotype antibodies to RBCV of any response group (Fig. 1F, 1G, 1H, 1I and 1J). The level of IgG2 for these cattle started with an $\mathrm{OD}_{450}$ value of $0.84 \pm 0.15$ on day 0 , increased during the following 2 weeks to $\mathrm{OD}_{450}$ value of $1.12 \pm 0.15$ on day 14 , and was then maintained.

\section{Antigenicity of RBCV structural proteins}

Antibody responses to specific viral structural proteins in immunoblotting assays revealed similar reactions among the cattle of each response group, and representative results from a single calf in each response group are presented. Figure 2 illustrates the immunoblotting reactions for calf 97TXSF-105 of response group 1 which shed RBCV in nasal secretions on day 7. Antibodies directed against viral structural proteins were not detectable in the serum samples collected on day 0 and day 7, but antibodies of rising levels reacting with $\mathrm{HE}$ and $\mathrm{S}$ were detected on day 14. Cattle of response group 2 developed HE- and S-specific antibodies on day 14, similar to response group 1. Sera from RBCV isolation-positive and fatal cases of response group 3 failed to react with any of the RBCV structural proteins (data not shown). 


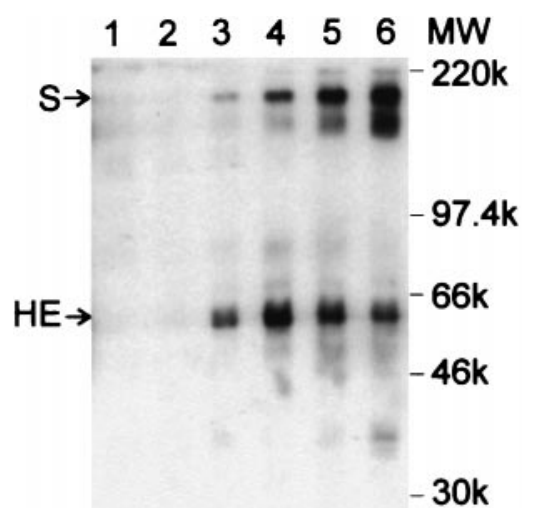

Fig. 2. Representative western blot analysis of sera

-21.5k from calf 97TXSF-105 of response group 1. 1-6 were probed with serum samples collected on day $0,7,14$, 21,28 and 35 , respectively
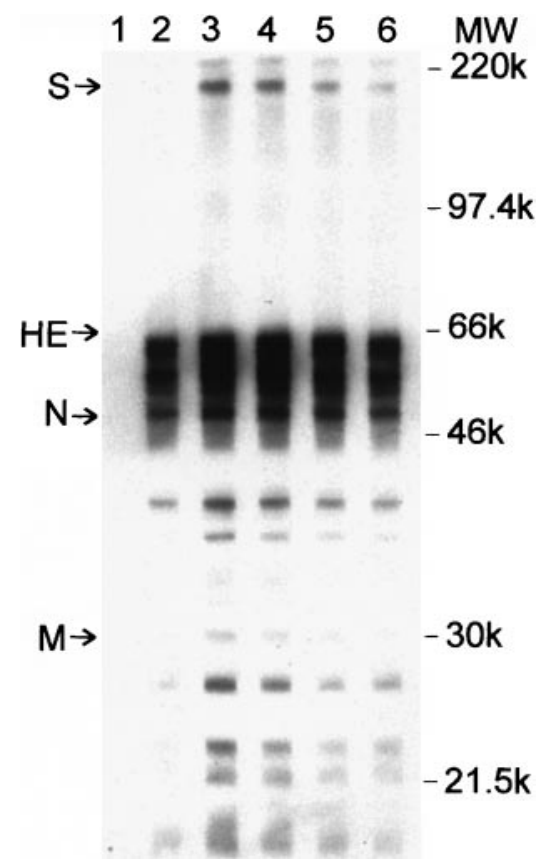

Fig. 3. Representative western blot analysis of sera from calf 97TXSF-88 of response group 4. 1-6 were probed with serum samples collected on day $0,7,14$, 21,28 and 35 , respectively

Western blot analysis of serum samples collected from RBCV isolationnegative calf 97TXSF-88 of response group 4 which had transient signs of respiratory distress is presented in Fig. 3. Strong antibody bindings of HE, S, and N viral proteins were detected on day 7 as cattle arrived in the feed yard, and were maintained for the following 4 weeks. Antibodies directed toward M glycoprotein were detectable at low level on day 14 and 21, waned on day 28, and disappeared on day 35 . 
X. Q. Lin et al.

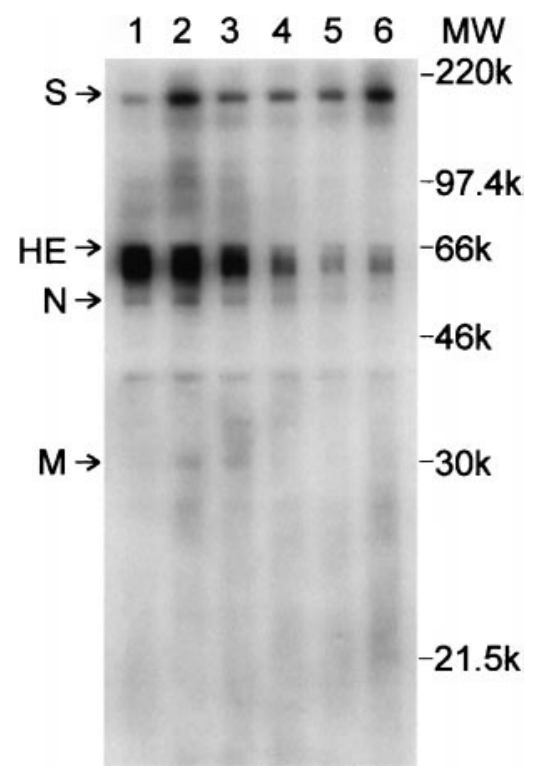

Fig. 4. Representative western blot analysis of sera from calf 97TXSF-4 of response group 5. 1-6 were probed with serum samples collected on day $0,7,14$, 21,28 and 35 , respectively

Figure 4 presents immunoblot reactivities of sera from calf 97TXSF-4 of response group 5 that remained clinically healthy and RBCV isolation-negative throughout the epizootic. The sera contained high levels of specific antibodies to $\mathrm{HE}, \mathrm{S}$ and $\mathrm{N}$ viral proteins on day 0 . The HE- or $\mathrm{N}$-specific antibodies in the subsequent serum samples began to decline 3 weeks later, while the $S$ antibody level was maintained or even increased during the next 5 weeks. The $M$ glycoprotein-specific band became visible on day 7, and disappeared 2 weeks later.

\section{Discussion}

Isolation results for RBCV and overt signs of respiratory tract disease divided the cattle of this experimentally assessed SF epizootic into 5 response groups. The majority of cattle (response groups 1 and 2) nasally shed RBCV in the early stage of the epizootic. Their initial total antibody levels were low and rapidly increased during the first 2 weeks through brisk responses to $\mathrm{HE}$ and $\mathrm{S}$ antigens. Increase in IgM appeared first, and was followed by rises in IgG1 and IgG2 as is characteristic for primary immune responses to antigens. Nasal RBCV shedding of most cattle ceased with the appearance of HE- and S-specific antibodies. This relationship between the RBCV infections and antibody responses can be explained by previous findings in EBCV and human respiratory coronavirus infections which revealed that $\mathrm{S}$ and $\mathrm{HE}$ elicited virus-neutralizing antibodies [6, $26,27]$. These findings differed from a previous report on antibody responses of newborn calves [10] because $\mathrm{N}$-specific antibodies were not detected during the primary immune responses to RBCV infection of these immunologically mature cattle. Based on our virus isolation results and the detected antibody levels, we concluded that most of these cattle became naturally infected with RBCV shortly 
before they were assembled at the OBB, and that virus spread was enhanced by stressful conditions during transport and associated crowding.

During the primary immune responses to RBCV, a significantly higher IgM level in the first week and a substantially higher IgG2 level for the last 3 weeks were observed in clinically sick cattle (response group 1) as compared to cattle without adverse respiratory signs (response group 2). Seroconversion was observed in calves between the $14^{\text {th }}$ and the $21^{\text {st }}$ days after intranasal vaccination with modified-live virus of infectious bovine rhinotracheitis (IBR) [16]. The neutralizing activity in the serum was low at the $14^{\text {th }}$ day, but increased by day 21 , and persisted for 2 or 3 months. Other investigators studied primary immune responses of seronegative cattle to IBR after intramuscular or nasal inoculations $[23,24]$. They demonstrated an early, transient and complement-dependent IgM antibody response followed by a complement-requiring $\mathrm{IgG}$ antibody response. Bovine complement component 3 (C3) activation was reported to be enhanced by bovine respiratory syncytial virus (BRSV)-specific IgM and IgG1, but not by IgG2 [13]. In the study of the pathogenesis of BRSV-associated disease, C3 was demonstrated in BRSV-infected parts of the lungs of dead calves, and was suggested to play a role in causing severe dyspnoea [14]. Possibly, RBCV might have induced adverse respiratory signs in a pathological mechanism similar to IBR and BRSV through early primary high levels of complement-binding but non-neutralizing antibodies on RBCV-infected cells. The precise role of complement components in the pathogenesis of RBCV-induced respiratory tract diseases should be studied further.

Investigation of fatal cases (response group 3) revealed that the calves were immunologically naïve to RBCV antigens. Antibody responses to any of the major viral structural proteins could not be detected with a sensitive immunoblotting assay. Lack of protective immunity or inability to develop HE- and S-specific virus-neutralizing antibodies against RBCV evidently resulted in acute infections of lungs which were further complicated by Pasteurella haemolytica infections, leading to fatal outcomes, typical for SF pneumonia [11, 41].

Cattle with respiratory disease signs but not shedding RBCV (response group 4) had relatively high levels of total antibody against RBCV on day 0. Strong RBCV-specific antibody responses against HE, $\mathrm{S}$ and $\mathrm{N}$ viral proteins had been mounted by the time of their arrival in the feed yard. These findings mirrored the late phase of a primary antibody response to the RBCV infections. Failure in $\mathrm{RBCV}$ isolation attempts probably was due to sampling during declining virus excretion. Additionally, RBCV infectivity in nasal secretions might have been neutralized by secretory antibodies through formation of antibody-virus complexes. Secretory IgA against RBCV was detected in nasal secretions of these cattle (data not shown). These cattle may have played an important role in introducing the RBCV into the large group of susceptible cattle in this severe epizootic.

During the 5-week investigation, 7 cattle remained healthy and RBCV isolation-negative (response group 5). These cattle had the highest level of IgG2 antibody against RBCV for the entire period of the epizootic, and antigens recognized were $\mathrm{HE}, \mathrm{S}$ and $\mathrm{N}$ viral proteins. The $\mathrm{S}$-specific antibody was more stable 
and persistent than the HE- and N-specific antibodies during the later course of the epizootic. However, antibody reactions with M protein were sporadically detected throughout the sampling period. The serological response patterns of these RBCV-resistant cattle characterized a secondary antibody response to RBCV, the type of protective immunity induced by recovery from initial infection or by effective vaccination and subsequent challenge exposure. Consequently, it was inferred that these cattle had been infected with RBCV, and had recovered from the infections before they were assembled at the OBB. Solid immunity from the initial infection prevented RBCV reinfection throughout this epizootic.

A major difference observed in immune responses between RBCV isolationnegative cattle with or without signs of respiratory tract diseases was the ratio of IgG2 to IgG1 which was higher for clinically normal cattle than sick ones. The bovine serum IgG1 has a shorter half-life than IgG2 [22]. Studies on the phagocytosis of Staphylococcus aureus by bovine polymorphonuclear neutrophils (PMN) indicated that $\mathrm{IgG} 2$ was opsonic for bovine PMN, while IgG1 was not opsonic, and even inhibited IgG2 opsonization [9]. In contrast to IgG2, IgG1 caused neither adherence nor phagocytosis in vitro by freshly isolated bovine neutrophils and monocytes [18]. Competitive inhibition tests indicated that binding of IgG2 exceeded that of IgG1, although IgG1 and $\mathrm{IgG} 2$ shared a common Fc receptor on bovine PMN $[19,40]$. Re-exposure of cattle to IBR virus resulted in a booster effect on serum antibodies including a transient IgM response as well as a further rapid increase in $\operatorname{IgG}[23,24]$. However, secondary antibody responses seemed to be less responsive to complement enhancement of the neutralizing activity. We hypothesized that during the secondary antibody response to RBCV, free RBCV and RBCV-infected cells were opsonized by high titers of opsonic and RBCVneutralizing $\operatorname{IgG} 2$, leading to enhanced phagocytosis, more efficient elimination of RBCV infectivity, and thus alleviation of clinical signs of respiratory tract disease.

Remarkable differences were observed in the antibody responses to the major structural proteins of RBCV. The M protein was much less immunogenic than $\mathrm{S}$, $\mathrm{HE}$, and $\mathrm{N}$ viral proteins. This observation can be explained by the low molecular mass, structural conformation and inaccessible location of $\mathrm{M}$ within the viral envelope. Both $\mathrm{HE}$ and $\mathrm{S}$ were the viral antigens recognized during the initial stages of the bovine immune response to RBCV infection. The HE glycoprotein induced antibodies earlier than the $\mathrm{S}$ glycoprotein. The HE glycoprotein consists of 2 identical, disulfide-linked glycosylated subunits with an N-terminal signal region and a $\mathrm{C}$-terminal anchorage region [15]. The $\mathrm{S}$ glycoprotein contains an $\mathrm{N}$ terminal signal sequence, a coil-to-coil structure, and a C-terminal hydrophobic membrane-anchoring domain, and exists as a more stable tetramer. The structure and abundance of the HE protein might favor exposure of epitopes with earlier induction of antibodies. The antibody response to $\mathrm{N}$ protein was pronounced during the later phase of the infection when RBCV shedding could not be detected by virus isolation attempts, but a modified PCR detected RBCV genomic regions in lung samples [3]. We hypothesized that the relatively late appearance of $\mathrm{N}$-specific antibodies might depend on the quantity of $\mathrm{N}$ in the virions, its 
structural binding to the RNA genome, and its internal site within the viral envelope. Findings on cell-mediated immunity to mouse hepatitis virus revealed that CD8-bearing lymphocytes influenced recovery from infection with $\mathrm{N}$ protein as the major target for cytotoxic lymphocytes [29]. Therefore, HE, S and N proteins should be the major viral antigens to be included in future vaccines for cattle to achieve efficient prevention of RBCV as well as EBCV infections.

\section{Acknowledgements}

We thank Dr. W. G. Henk for digital analysis of the immunoblots and Michael Kearney for statistical assessment, and appreciate the technical assistance of Ms. L. B. Cox and Mrs. P. Triche. These investigations were supported by grants from the Critical Issues and the National Research Initiative Programs of the United States Department of Agriculture (98-34362-6071, 94-37204-0926), the Louisiana Education Quality Support Fund (RF/1995-1998) RD-B-18 with matches from Immtech Biologics, LLC, Bucyrus, KS, and Bayer Corporation, Merriam, KS, the Texas Agricultural Experiment Station Project H-3074 (Regional Research NC107), the Texas Advanced Technology Program (Grant No 999902), the Louisiana Beef Industry Council, and the School of Veterinary Medicine, Louisiana State University, Baton Rouge, LA.

\section{References}

1. Brown TDK, Brierly I (1995) The coronavirus non-structural proteins. In: Siddell SG (ed) The Coronaviridae. Plenum Press, New York, pp 191-217

2. Butler JE (1969) Bovine immunoglobulins: a review. J Dairy Sci 52: 1895-1909

3. Chouljenko VN, Kousoulas KG, Lin XQ, Storz J (1998) Genetic analysis of respiratory bovine coronavirus strains from fatal pneumonia of cattle. Proceedings of the Seventyninth Conference of Research Workers on Animal Diseases, Chicago, Illinois, p 149

4. Chouljenko VN, Kousoulas KG, Lin XQ, Storz J (1998) Nucleotide and predicted amino acid sequences of all genes encoded by the $3^{\prime}$ genomic portion $(9.5 \mathrm{~kb})$ of respiratory bovine coronaviruses and comparisons among respiratory and enteric coronaviruses. Virus Genes 17: 33-42

5. Clark MA (1993) Bovine coronavirus. Br Vet J 149: 51-70

6. Deregt D, Gifford GA, Ijaz MK, Watts TC, Gilchrist JE, Haines DM, Babiuk LA (1989) Monoclonal antibodies to bovine coronavirus glycoproteins E2 and E3: demonstration of in vivo virus-neutralizing activity. J Gen Virol 70: 993-998

7. Deregt D, Sabara M, Babiuk LA (1987) Structural proteins of bovine coronavirus and their intracellular processing. J Gen Virol 68: 2863-2877

8. Duncan JR, Wilkie BN, Hiestand F, Winter AJ (1972) The serum and secretory immunoglobulins of cattle: characterization and quantitation. J Immunol 108: 965-976

9. Guidry AJ, Berning LM, Hambleton CN (1993) Opsonization of Staphylococcus aureus by bovine immunoglobulin isotypes. J Dairy Sci 76: 1285-1289

10. Heckert RA, Saif LJ, Mengel JP, Myers GW (1991) Isotype-specific antibody responses to bovine coronavirus structural proteins in serum, feces, and mucosal secretions from experimentally challenge-exposed colostrum-deprived calves. Am J Vet Res 52: 692-699

11. Hoerlein AB (1980) Shipping fever in bovine medicine and surgery. In: Amstutz HE (ed) Bovine medicine and surgery. American Veterinary Publications, Santa Barbara, pp 99-106 
12. Hogue BG, Kienzle TE, Brian DA (1989) Synthesis and processing of the bovine enteric coronavirus hemagglutinin protein. J Gen Virol 70: 345-352

13. Kimman TG, Daha MR, Brinkhof JMA, Westenbrink F (1989) Activation of complement by bovine respiratory syncytial virus-infected cells. Vet Immunol Immunopathol 21: 311-325

14. Kimman TG, Terpstra GK, Daha MR, Westenbrink F (1989) Pathogenesis of naturally acquired bovine respiratory syncytial virus infection in calves: evidence for the involvement of complement and mast cell mediators. Am J Vet Res 5: 694-700

15. Lai MMC (1990) Coronavirus: organization, replication and expression of genome. Annu Rev Microbiol 44: 303-333

16. LeJan C, Asso J (1980) The local and systemic immune response of calves following experimental infection with IBR virus. In: Butler JE (ed) The ruminant immune system. Plenum Press, New York, pp 677-692

17. Lin XQ, Chouljenko VN, Kousoulas KG, Storz J (2000) Hemagglutinin-esterase specified by respiratory bovine coronaviruses has temperature-sensitive acetylesterase activity. J Med Microbiol 49: 849-864

18. McGuire TC, Musoke AJ (1980) Biologic activities of bovine IgG subclasses. In: Butler JE (ed) The ruminant immune system. Plenum Press, New York London, pp 359-366

19. McGuire TC, Musoke AJ, Kurtti T (1979) Functional properties of bovine IgG1 and $\mathrm{IgG} 2$ : interaction with complement, macrophages, neutrophils and skin. Immunology 38: $249-256$

20. McGuire TC, Pfeiffer ND, Weikel JM, Bartsch RC (1976) Failure of colostral immunoglobulin transfer in calves dying from infectious disease. J Am Vet Med Assoc 169: 713-718

21. Mebus CA, Stair EL, Rhodes MB, Twiehaus MJ (1973) Neonatal calf diarrhea: Propagation, attenuation, and characteristics of a corona-like agent. Am J Vet Res 34: 145-150

22. Nansen P (1970) Metabolism of bovine immunoglobulin-G. Thesis, Royal Veterinary and Agricultural University, Copenhagen

23. Potgieter LND (1975) The influence of complement on the neutralization of IBR by globulins derived from early and late bovine antisera. Can J Comp Med 39: 427-433

24. Rossi CR, Kisesel GK (1976) Antibody class and complement requirement of neutralizing antibodies in the primary and secondary response of cattle to IBR vaccines. Arch Virol 51: 191-196

25. Saif LJ, Redman DR, Brock KV, Kohler EM, Heckert RA (1988) Winter dysentery in adult dairy cattle: detection of coronavirus in the feces. Vet Rec 123: 300-301

26. Schmidt OW, Kenny GE (1982) Polypeptides and functions of antigens from human coronaviruses 229E and OC43. Infect Immun 32: 1000-1006

27. Schultze B, Herrler G (1992) Bovine coronavirus uses N-acetyl-9-O-acetyl-neuraminic acid as a receptor determinant to initiate the infection of cultured cells. J Gen Virol 74: 901-906

28. Spaan W, Cavanagh D, Horzinek MC (1988) Coronavirus: structure and genome expression. J Gen Virol 69: 2939-2952

29. Stohlman SA, Kyuwa S, Polo JM, Brady D, Lai MMC, Bergmann CC (1993) Characterization of mouse hepatitis virus-specific cytotoxic T cells derived from the central nervous system of mice infected with the JHM strain. J Virol 67: 7050-7059

30. Storz J (1998) Respiratory disease of cattle associated with coronavirus infections. In: Howard JL, Smith RA (ed) Current veterinary therapy: food animal practice 4. WB Saunders, Philadelphia, pp 291-293

31. Storz J, Lin XQ, Purdy CW, Loan RW (1999) Novel diagnostics for defining virus infections in shipping fever pneumonia: emergence of respiratory bovine coronaviruses. 
Proceedings of the Fourth International Symposium of World Association of Veterinary Laboratory Diagnosticians, College Station, pp 54-60

32. Storz J, Lin XQ, Purdy CW, Chouljenko VN, Kousoulas KG, Enright FM, Gilmore WC, Briggs RE, Loan RW (2000) Coronavirus and Pasteurella infections in bovine shipping fever pneumonia and Evans' criteria of causation. J Clin Microbiol 38: 3082-3090

33. Storz J, Purdy CW, Lin XQ, Burrell M, Truax RE, Briggs RE, Frank GH, Loan RW (2000) Isolation of respiratory bovine coronavirus, other cytocidal viruses, and Pasteurella spp from cattle involved in two natural outbreaks of shipping fever. J Am Vet Med Assoc 216: $1-6$

34. Storz J, Rott R (1980) Über die Verbreitung der Coronavirusinfektion bei Rindern in ausgewählten Gebieten Deutschlands: Antikörpernachweis durch Mikroimmundiffusion und Neutralisation. Dtsch Tierärztl Wochenschr 87: 252-254

35. Storz J, Rott R (1981) Reactivity of antibodies in human serum with antigens of an enteropathogenic bovine coronavirus. Med Microbiol Immunol 169: 169-178

36. Storz J, Rott R, Kaluza G (1981) Enhancement of plaque formation and cell fusion of an enteropathogenic coronavirus by trypsin treatment. Infect Immun 31: 1214-1222

37. Storz J, Stine L, Liem A, Anderson GA (1996) Coronavirus isolation from nasal swab samples of cattle with signs of respiratory tract disease after shipping. J Am Vet Med Assoc 208: 1452-1454

38. Storz J, Zhang XM, Rott R (1992) Comparison of hemagglutinating, receptor-destroying, and acetylesterase activities of avirulent and virulent bovine coronavirus strains. Arch Virol 125: 193-204

39. Williams MR, Spooner RL (1975) Quantitative studies on bovine immunoglobulins. Vet Rec 96: 81-84

40. Worku M, Paape MJ, Marquardt WW (1994) Modulation of Fc receptors for IgG on bovine polymorphonuclear neutrophils by interferon- $\gamma$ through de novo RNA transcription and protein synthesis. Am J Vet Res 55: 234-238

41. Yates WDG (1982) A review of infectious bovine rhinotracheitis, shipping fever pneumonia and viral-bacterial synergism in respiratory disease of cattle. Can J Comp Med 46: $225-263$

42. Zhang XM, Herbst W, Kousoulas KG, Storz J (1994) Biological and genetic characterization of a hemagglutinating coronavirus isolated from a diarrhoeic child. J Med Virol 44: $152-161$

Authors' address: Dr. J. Storz, Department of Veterinary Microbiology and Parasitology, Louisiana State University School of Veterinary Medicine, Baton Rouge, LA 70803, U.S.A.

Received December 13, 1999 